\title{
Predicting the Outcome of Patients with Lower Urinary Tract Symptoms due to Benign Prostatic Hyperplasia Treated with Alpha Blocker Monotherapy by Measurement of Bladder and Prostate Parameters Using Ultrasound
}

\author{
TAREK A. ZAGHLOUL, M.Sc.; SALAH A. NAGLA, M.D.; MOHAMED H. RADWAN, M.D. and \\ ABD EL-NASER K. EL-GAMASY, M.D.
}

The Department of Urology, Faculty of Medicine, Tanta University, Egypt

\begin{abstract}
Background: Benign Prostatic Hyperplasia (BPH) is a condition intimately related to ageing. Although it is not life threatening, its clinical manifestation as Lower Urinary Tract Symptoms (LUTS) reduces the patient's quality of life.

Aim of the Study: To determine prostate and bladder sonographic parameters that can predict the outcome of patients with LUTS/BPH treated by alpha 1a adrenoreceptor blocker monotherapy.

Patients and Methods: Fifty patients complaining of LUTS/BPH were prospectively enrolled. Transrectal Ultrasonography (TRUS) was done to all patients. Tamsulosin $0.4 \mathrm{mg}$ oral tablet was given to all patients once daily for 3 months then the response to treatment on the basis of International Prostatic Symptom Score (IPSS), Quality of Life (QoL) score and maximum urine flow rate (Qmax) was evaluated. The impacts of baseline parameters on treatment outcome were statistically analyzed.

Results: 45 patients completed the study. From them 15 patients $(33.3 \%)$ had ineffective treatment. Pre treatment IPSS storage subscore, Qmax and TRUS measured parameters [Bladder Wall Thickness (BWT), Intravesical Prostatic Protrusion (IPP) and ultrasound estimated bladder weight (UEBW)] were the independent predictors of treatment failure. Receiver Operator characteristic (ROC) curves for parameters (BWT, UEBW and IPP) showed that Areas Under Curve (AUC) were $(0.870,0.908$ and 0.836 respectively) at cut-off values of $9 \mathrm{~mm}, 36 \mathrm{~g}$ and $8.2 \mathrm{~mm}$. Using these cut-off values, the Positive Predictive Value (PPV) and Negative Predictive Value (NPV) were $75.0 \%$ and $97.6 \% ; 72.4 \%$ and $96.0 \%$; $67.5 \%$ and $95.0 \%$ for BWT, UEBW and IPP, respectively. Combination of these sono-morphologic parameters increased their positive predictive value to $76.39 \%$.
\end{abstract}

Conclusion: Combined use of sonographic parameters BWT, UEBW and IPP can predict alpha blocker monotherapy failure in BPH patients which aid in determining therapeutic plan and the need for further medical therapy or surgical intervention.

Correspondence to: Dr. Tarek A. Zaghloul, The Department of Urology, Faculty of Medicine, Tanta University, Egypt
Key Words: Alpha blockers monotherapy - Benign prostatic hyperplasia - Medical treatment - Ultrasonography.

\section{Introduction}

MEDICAL and surgical treatments are available for LUTS/BPH. As regard the medical treatment a lot of drugs can be used and choosing the correct medical treatment is sophisticated. Further, it is hard to predict who will respond, or which drug or drug combination will be better for an individual patient [1]

Alpha blockers were the most commonly used drugs in the medical treatment of BPH. However, medical therapy has its own limitations and its failure results in worsening of symptoms and development of complications [2]

The impact and predictive value of some clinical and sonographic parameters on BPH medical treatment outcome were assessed in several studies [3-5].

Each of these studies assessed each parameter alone and one study $[6]$ assessed the prospective analysis of combined sono morphological parameters in predicting the outcome of LUTS/BPH medical treatment for 6 months which is a long duration according to the rapid action of alpha blockers.

In this study we assessed the clinical outcome of LUTS/BPH patients treated with alpha blocker tamsulosin for 3 months and determined clinical and morphological parameters that had significant impact on the treatment outcome also the predictive value of these parameters was assessed. 


\section{Patients and Methods}

This prospective non randomized study was conducted on fifty symptomatic patients complaining of LUTS/BPH seeking treatment at Urology Department, Tanta University Hospitals through the period from June 2016 up to June 2017.

Patients were evaluated by complete history taking including IPSS and QoL scores, clinical examination, urine analysis, urine culture, serum creatinine, serum Prostatic Specific Antigen (PSA), uroflowmetery, measurement of Post-Void Residual (PVR) urine volume, transabdominal and transrectal ultrasonography (TRUS).

Only patients with moderate or severe LUTS, more than 45 years old, prostate size less than $45 \mathrm{~g}$ and Qmax $<15 \mathrm{ml} / \mathrm{s}$ were included. Patients with history of taking drugs that affect voiding patterns, allergy to Alpha 1 blockers, diabetes mellitus, urethral stricture, urinary tract infection, renal insufficiency, suspicious prostate cancer on examination or PSA, high PVR urine volume $>200 \mathrm{ml}$ and indwelling urethral catheterization were excluded from the study.

Trans-abdominal ultrasound was done in supine position at bladder volume of $100-200 \mathrm{ml}$ using BK medical, flex focus ultrasound system. Bladder volume was measured using the $3.5 \mathrm{MHz}$ convex probe by prolate ellipsoid method; volume = (Length) X (width) X (height) X 0.52 .

Bladder Wall Thickness (BWT) was measured using the $7.5 \mathrm{MHz}$ linear probe. Bladder wall is formed of detrusor muscle which is represented by a hypoechoic layer between two hyperechoic layers which are the serosa and mucosa, BWT was measured as the hypoechoic layer between the 2 hyperechoic layers.

Ultrasound Estimated Bladder Weight (UEBW) was calculated from the known bladder volume and BWT.

Trans rectal ultrasound was performed in left lateral decubitus position at bladder volume of $100-200 \mathrm{ml}$ using trans rectal probe of BK medical, flex focus ultrasound system.

Total Prostate Volume (TPV) was measured using prolate ellipsoid method; volume $=($ Length $)$ $\mathrm{X}$ (width) X (height) X 0.52 .

Intra vesical prostatic protrusion (IPP) was measured using a midline sagittal image and drawing a line through the bladder base then IPP meas- ured as vertical distance from the tip of protrusion to the bladder base Fig. (1).

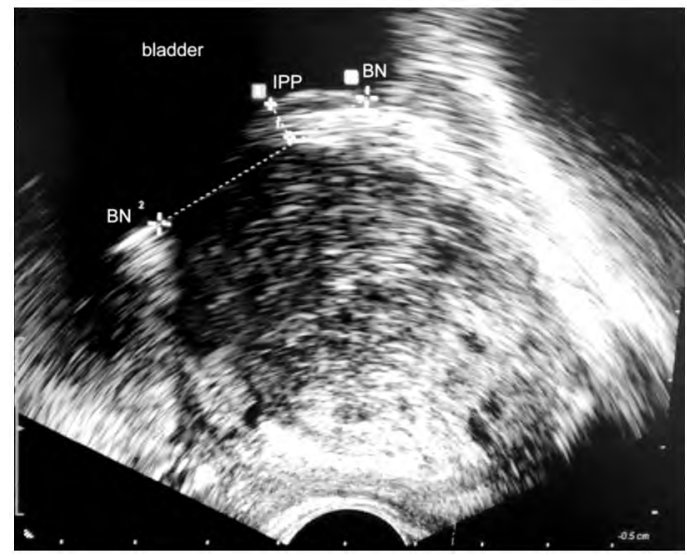

Fig. (1): IPP measurement in sagittal plane.

IPP: Intravesical Prostatic Protrusion. BN: Bladder Neck.

Transitional zone volume (TZV) was scanned in transverse and sagittal planes using prolate ellipsoid method; volume $=($ Length $) \mathrm{X}$ (width) $\mathrm{X}$ (height) X 0.52 .

Tamsulosin $0.4 \mathrm{mg}$ oral tablet was given once daily for 3 months then patients were followed-up by measuring the values of (IPSS) score, (QoL) score and (Qmax) using uroflowmetry.

Treatment outcome was determined by comparing pre-treatment and 3 months post-treatment follow-up values of I-PSS, QoL score and Qmax.

Efficacy was graded as poor, fair, good and excellent for each aspect, then the overall efficacy was calculated from the median grade of the 3 aspects and considered effective for excellent and good grades and ineffective for fair and poor grades [5]. Clinical, laboratory and sonographic data were analyzed.

\section{Statistical analysis:}

IBM SPSS software package Version 20.0 (Armonk, NY: IBM Corp) was used to analyze the data. Kolmogorov-Smirnov test was performed to verify the normality of data distribution. Quantitative data were described using range, mean, standard deviation and median. Student's $t$-test, MannWhitney U-test or Chi-square tests were used and stepwise forward logistic regression analysis was performed to determine the independent factors of ineffective treatment. Receiver Operating Characteristics (ROC) curve analysis was performed to identify the predictive performance of sonographic parameters. $p<0.05$ was accepted to indicate a significant difference with a power of $80 \%$. 


\section{Ethical considerations:}

There are adequate provisions to maintain privacy of participants and confidentiality of the data as every patient had a code number, the name and the address were kept in a special private file linked to the research, the results of the study were used only for scientific purpose and not for any other purposes. The ethical committee approval was taken under the number (30995/06/16) also an informed consent was obtained from all participants in this research after full explanation of benefits and risks of the study.

Risks on the participants in this study and how was managed:

Allergic reaction to alpha blockers: No patients developed any allergic symptoms to alpha blocker.
Development of complications during study period: 3 patients developed complications; 1 had attack of acute urinary retention and 2 had hematuria, the treatment was stopped and the patients were shifted to surgical intervention.

\section{Results}

Out of 50, 45 patients completed the examinations and follow-up, 3 patients developed complications and shifted to surgery and 2 patients lost on follow-up. Comparison of baseline IPSS score, QoL score and Qmax values with that at the end of study showed that tamsulosin significantly improved the I-PSS, QoL score and Qmax values $(p<0.001)$. (Table 1).

Table (1): Baseline IPSS, QoL score, Qmax and follow-up data.

\begin{tabular}{|c|c|c|c|c|c|}
\hline & $\begin{array}{l}\text { Total } \\
(\mathrm{n}=45)\end{array}$ & $\begin{array}{l}\text { Effective } \\
\quad(n=30)\end{array}$ & $\begin{array}{c}\text { Ineffective } \\
\quad(n=15)\end{array}$ & $\begin{array}{l}\text { Test } \\
\text { of sig. }\end{array}$ & $\begin{array}{c}p- \\
\text { value }\end{array}$ \\
\hline $\begin{array}{l}\text { IPSS: } \\
\text { • Baseline: }\end{array}$ & & & & & \\
\hline $\begin{array}{l}\text { Min.-max. } \\
\text { Mean } \pm \text { SD. } \\
\text { Median }\end{array}$ & $\begin{array}{l}17.0-26.0 \\
19.60 \pm 2.19 \\
19.0\end{array}$ & $\begin{array}{l}17.0-20.0 \\
18.53 \pm 1.20 \\
18.50\end{array}$ & $\begin{array}{l}19.0-26.0 \\
21.73 \pm 2.19 \\
21.0\end{array}$ & $\begin{array}{l}\mathrm{U}= \\
45.0^{*}\end{array}$ & $<0.001 *$ \\
\hline $\begin{array}{l}\text { Post ttt: } \\
\text { Min.-max. } \\
\text { Mean } \pm \text { SD. } \\
\text { Median } \\
p_{1} \text {-value }\end{array}$ & $\begin{array}{l}3.0-18.0 \\
8.84 \pm 4.09 \\
8.0 \\
<0.001 *\end{array}$ & $\begin{array}{l}3.0-9.0 \\
6.30 \pm 1.99 \\
7.0 \\
<0.001 *\end{array}$ & $\begin{array}{l}12.0-18.0 \\
13.93 \pm 1.67 \\
14.0 \\
<0.001 *\end{array}$ & $\begin{array}{l}\mathrm{U}= \\
0.000 *\end{array}$ & $<0.001 *$ \\
\hline $\begin{array}{l}\text { Qol score: } \\
\text {-Baseline: } \\
\text { Min.-max. } \\
\text { Mean } \pm \text { SD. } \\
\text { Median }\end{array}$ & $\begin{array}{l}3.0-4.0 \\
3.76 \pm 0.43 \\
4.0\end{array}$ & $\begin{array}{l}3.0-4.0 \\
3.63 \pm 0.49 \\
4.0\end{array}$ & $\begin{array}{l}4.0-4.0 \\
4.0 \pm 0.0 \\
4.0\end{array}$ & $\begin{array}{l}\mathrm{U}= \\
142.5^{*}\end{array}$ & $0.008^{*}$ \\
\hline $\begin{array}{l}\text { Post ttt: } \\
\text { Min.-max. } \\
\text { Mean } \pm \text { SD. } \\
\text { Median } \\
p_{1} \text {-value }\end{array}$ & $\begin{array}{l}0.0-3.0 \\
1.40 \pm 1.19 \\
1.0 \\
<0.001 *\end{array}$ & $\begin{array}{l}0.0-3.0 \\
0.80 \pm 0.96 \\
1.0 \\
<0.001 *\end{array}$ & $\begin{array}{l}2.0-3.0 \\
2.60 \pm 0.51 \\
3.0 \\
<0.001 *\end{array}$ & $\begin{array}{l}\mathrm{U}= \\
37.50^{*}\end{array}$ & $p$ 2value \\
\hline $\begin{array}{l}\text { Qmax }(\mathbf{m l} / \mathbf{s}): \\
\text { - Baseline: }\end{array}$ & & & & & \\
\hline $\begin{array}{l}\text { Min.-max. } \\
\text { Mean } \pm \text { SD. } \\
\text { Median }\end{array}$ & $\begin{array}{l}7.0-13.0 \\
9.30 \pm 1.42 \\
9.0\end{array}$ & $\begin{array}{l}8.50-13.0 \\
10.03 \pm 1.07 \\
9.85\end{array}$ & $\begin{array}{l}7.0-9.0 \\
7.83 \pm 0.70 \\
8.0\end{array}$ & $\begin{array}{l}t= \\
7.193^{*}\end{array}$ & $<0.001 *$ \\
\hline $\begin{array}{l}\text { Post ttt: } \\
\text { Min.-max. } \\
\text { Mean } \pm \text { SD. } \\
\text { Median } \\
p_{3} \text {-value }\end{array}$ & $\begin{array}{l}9.10-19.0 \\
14.80 \pm 3.08 \\
15.80 \\
<0.001 *\end{array}$ & $\begin{array}{l}14.0-19.0 \\
16.75 \pm 1.32 \\
16.60 \\
<0.001 *\end{array}$ & $\begin{array}{l}9.10-13.0 \\
10.89 \pm 1.32 \\
10.90 \\
<0.001 *\end{array}$ & $\begin{array}{l}t= \\
14.042 *\end{array}$ & $<0.001 *$ \\
\hline
\end{tabular}


- As regard symptoms response (IPSS) to therapy it was calculated as:

Post ttt I-PSS/pre ttt I-PSS: 30 patients were effective as regard symptoms response, all of them were effective according to the overall efficacy and 15 patients were ineffective as regard symptoms response, all of them were ineffective according to the overall efficacy (Table 2).

- As regard Quality of Life (QoL) response to therapy it was calculated as:

Pre ttt QoL minus post ttt QoL score: 25 patients were effective as regard QoL response, all of them were effective according to the overall efficacy, while 20 patients were ineffective as regard QoL response with 5 patients from them were effective according to the overall efficacy and the remaining 15 patients were ineffective according to the overall efficacy (Table 2).

- As regard voiding function response (Qmax) to therapy it was calculated as:

Post ttt Qmax minus pre ttt Qmax: 31 patients were effective as regard voiding function response, 30 patients were effective according to the overall efficacy and 1 patient was ineffective according to the overall efficacy. While 14 patients were ineffective as regard symptoms response, all of them were ineffective according to the overall efficacy. (Table 2).

Table (2): Symptoms, QoL and voiding function response to tamsulosin therapy.

\begin{tabular}{|c|c|c|c|c|c|c|c|c|}
\hline & \multicolumn{2}{|c|}{$\begin{array}{l}\text { Total } \\
(\mathrm{n}=45)\end{array}$} & \multicolumn{2}{|c|}{$\begin{array}{l}\text { Effective } \\
\quad(n=30)\end{array}$} & \multicolumn{2}{|c|}{$\begin{array}{l}\text { Ineffective } \\
\quad(n=15)\end{array}$} & \multirow{2}{*}{$\begin{array}{l}\text { Test } \\
\text { of sig. }\end{array}$} & \multirow{2}{*}{$\begin{array}{c}p- \\
\text { value }\end{array}$} \\
\hline & No. & $\%$ & No. & $\%$ & No. & $\%$ & & \\
\hline \multicolumn{9}{|c|}{ - Symptoms response (post } \\
\hline ttt/pre ttt IPSS): & & & & & & & & $<0.001 *$ \\
\hline Excellent $(\leq 0.25)$ & 10 & 22.2 & 10 & 33.3 & 0 & 0.0 & $\chi^{2}=$ & \\
\hline Good $(>0.25-\leq 0.5)$ & 20 & 44.4 & 20 & 66.7 & 0 & 0.0 & $45.0^{*}$ & \\
\hline Fair $(>0.5-\leq 0.75)$ & 15 & 33.3 & 0 & 0.0 & 15 & 100.0 & & \\
\hline Poor $(>0.75)$ & 0 & 0.0 & 0 & 0.0 & 0 & 0.0 & & \\
\hline Min.-max. & \multicolumn{2}{|c|}{$0.16-0.75$} & \multicolumn{2}{|c|}{$0.16-0.50$} & \multicolumn{2}{|c|}{$0.54-0.75$} & $t=$ & $<0.001 *$ \\
\hline Mean \pm SD & \multicolumn{2}{|c|}{$0.44 \pm 0.17$} & \multicolumn{2}{|c|}{$0.34 \pm 0.11$} & \multicolumn{2}{|c|}{$0.64 \pm 0.06$} & $12.252 *$ & \\
\hline Median & \multicolumn{2}{|c|}{0.44} & \multicolumn{2}{|c|}{0.35} & \multicolumn{2}{|c|}{0.63} & & \\
\hline \multicolumn{9}{|c|}{ - Quality of life response (pre } \\
\hline \multicolumn{9}{|c|}{ ttt -post ttt QoL score): } \\
\hline Excellent (4-6) & 3 & 6.7 & 3 & 10.0 & 0 & 0.0 & $\chi^{2}=$ & $\mathrm{MC}_{p}$ \\
\hline Good (3) & 22 & 48.9 & 22 & 73.3 & 0 & 0.0 & $29.789 *$ & $<0.001 *$ \\
\hline Fair (1-2) & 20 & 44.4 & 5 & 16.7 & 15 & 100.0 & & \\
\hline Poor (0) & 0 & 0.0 & 0 & 0.0 & 0 & 0.0 & & \\
\hline Min.-max. & \multicolumn{2}{|c|}{$1.0-4.0$} & \multicolumn{2}{|c|}{$1.0-4.0$} & \multicolumn{2}{|c|}{$1.0-2.0$} & $\mathrm{U}=$ & $<0.001 *$ \\
\hline Mean \pm SD & \multicolumn{2}{|c|}{$2.36 \pm 0.96$} & \multicolumn{2}{|c|}{$2.83 \pm 0.75$} & \multicolumn{2}{|c|}{$1.40 \pm 0.51$} & $37.50^{*}$ & \\
\hline Median & \multicolumn{2}{|c|}{3.0} & \multicolumn{2}{|c|}{3.0} & \multicolumn{2}{|c|}{1.0} & & \\
\hline \multicolumn{9}{|c|}{$\begin{array}{l}\text { - Voiding function response } \\
\text { (post ttt -pre ttt Qmax): }\end{array}$} \\
\hline Excellent $>10$ & 0 & 0.0 & 0 & 0.0 & 0 & 0.0 & $\chi^{2}=$ & $\mathrm{MC}_{p}$ \\
\hline Good (5-10) & 31 & 68.9 & 30 & 100.0 & 1 & 6.7 & $42.078 *$ & $<0.001 *$ \\
\hline Fair $(\geq 2.5-5)$ & 7 & 15.6 & 0 & 0.0 & 7 & 46.7 & & \\
\hline Poor $(<2.5)$ & 7 & 15.6 & 0 & 0.0 & 7 & 46.7 & & \\
\hline Min.-max. & \multicolumn{2}{|c|}{$2.10-10.0$} & \multicolumn{2}{|c|}{$5.0-10.0$} & \multicolumn{2}{|c|}{$2.10-5.0$} & $t=$ & $<0.001 *$ \\
\hline Mean \pm SD & 5.48 & 2.10 & & 1.32 & & 0.91 & $9.539^{*}$ & \\
\hline Median & 5.6 & & & & 2. & & & \\
\hline $\begin{array}{l}\chi^{2}, p: \chi 2 \text { and } p \text {-values } \\
t, p: t \text { and } p \text {-values fo } \\
\mathrm{MC}_{p}: p \text {-value for Mont } \\
\mathrm{U}, p: \mathrm{U} \text { and } p \text {-values } \mathrm{f} \\
* \text { : Statistically signi }\end{array}$ & 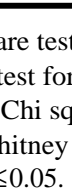 & com & & $n$ the $t$ & S. & ups. & & \\
\hline
\end{tabular}


The overall treatment efficacy rates were $66.7 \%$ to the effective group and $33.3 \%$ to the ineffective group (Table 3).

Patients in the ineffective treatment group experienced significantly higher I-PSS $(p<0.001)$, QoL score $(p=0.008)$, PVR urine volume $(p<0.001)$, BWT $(p<0.001)$, UEBW $(p<0.001)$, IPP $(p<0.001)$ and lower Qmax $(p<0.001)$ (Table 4).
Table (3): Distribution of the studied cases according to overall efficacy.

\begin{tabular}{ccl}
\hline Overall efficacy & No. of patients & $\%$ \\
\hline Effective: & 30 & 66.7 \\
Excellent & 3 & 6.7 \\
Good & 27 & 60.0 \\
Ineffective: & 15 & 33.3 \\
Fair & 15 & 33.3 \\
Poor & 0 & 0.0 \\
\hline
\end{tabular}

Table (4): Comparison between the 2 groups according to different parameters.

\begin{tabular}{|c|c|c|c|c|c|}
\hline & $\begin{array}{l}\text { Total } \\
(\mathrm{n}=45)\end{array}$ & $\begin{array}{l}\text { Effective } \\
(\mathrm{n}=30)\end{array}$ & $\begin{array}{l}\text { Ineffective } \\
\quad(n=15)\end{array}$ & $\begin{array}{c}\text { Test } \\
\text { of sig. }\end{array}$ & $\begin{array}{c}p- \\
\text { value }\end{array}$ \\
\hline \multicolumn{6}{|l|}{$T P V\left(\mathrm{~cm}^{3}\right):$} \\
\hline Min.-max. & $31.0-44.40$ & $31.0-43.20$ & $37.80-44.40$ & $t=$ & \multirow[t]{3}{*}{$<0.001 *$} \\
\hline Mean \pm SD & $37.35 \pm 3.99$ & $35.33 \pm 3.08$ & $41.37 \pm 2.04$ & $6.854 *$ & \\
\hline Median & 37.20 & 34.80 & 41.60 & & \\
\hline \multicolumn{6}{|l|}{$T Z V\left(\mathrm{~cm}^{3}\right):$} \\
\hline Min.-max. & $18.50-27.50$ & $18.50-27.20$ & $21.50-27.50$ & & \multirow{3}{*}{$<0.001$ * } \\
\hline Mean \pm SD & $22.94 \pm 2.93$ & $21.92 \pm 2.81$ & $24.99 \pm 1.97$ & $3.788^{*}$ & \\
\hline Median & 22.40 & 20.80 & 25.0 & & \\
\hline \multicolumn{6}{|l|}{$B W T(\mathrm{~mm}):$} \\
\hline Min.-max. & $3.80-13.10$ & $3.80-12.20$ & $9.60-13.10$ & & \multirow[t]{3}{*}{$<0.001 *$} \\
\hline Mean \pm SD & $8.25 \pm 2.47$ & $6.97 \pm 1.89$ & $10.80 \pm 1.16$ & $7.169^{*}$ & \\
\hline Median & 8.0 & 6.20 & 10.50 & & \\
\hline \multicolumn{6}{|l|}{$U E B W(g):$} \\
\hline Min.-max. & $22.70-44.20$ & $22.70-40.70$ & $37.60-44.20$ & & \multirow[t]{3}{*}{$<0.001 *$} \\
\hline Mean \pm SD. & $32.81 \pm 6.99$ & $29.0 \pm 5.20$ & $40.44 \pm 1.98$ & $10.609 *$ & \\
\hline Median & 31.40 & 27.75 & 40.30 & & \\
\hline \multicolumn{6}{|l|}{$\operatorname{IPP}(\mathrm{mm}):$} \\
\hline Min.-max. & $0.0-12.40$ & $0.0-12.30$ & $8.80-12.40$ & $\mathrm{U}=$ & \multirow[t]{3}{*}{$<0.001$ * } \\
\hline Mean \pm SD & $6.93 \pm 3.95$ & $5.23 \pm 3.75$ & $10.32 \pm 1.20$ & $64.50^{*}$ & \\
\hline Median & 7.20 & 4.20 & 10.20 & & \\
\hline
\end{tabular}

$t, p \quad: t$ and $p$-values for student $t$-test for comparing between the two groups.

$\bigcup, p: U$ and $p$-values for Mann Whitney test for comparing between the two groups.

: Statistically significant at $p \leq 0.05$

TPV : Total Prostate Volume.

TZV : Transitional Zone Volume.

BWT : Bladder Wall Thickness.

UEBW : Ultrasound Estimated Bladder Weight.

IPP : Intravesical Prostatic Protrusion.

Fig. (2) demonstrated the ROC curves of parameters (BWT, UEBW and IPP). The Area Under Curve (AUC) were $0.870(95 \% \mathrm{CI}=0.809-0.931$; $p<0.001$; cut-off value $9 \mathrm{~mm})$ for BWT, $0.908((95 \%$ $\mathrm{CI}=0.851-964 ; p<0.001$; cut-off value $36 \mathrm{~g})$ for UEBW and $0.836(95 \%$ CI $=0.774-0.898 ; p<0.001$; cut-off value $8.2 \mathrm{~mm}$ ) for IPP.

Using the previous cut-off values, the Positive Predictive Value (PPV) and Negative Predictive Value (NPV) were $75.0 \%$ and $97.6 \% ; 72.4 \%$ and $96.0 \% ; 67.5 \%$ and $95.0 \%$ for BWT, UEBW and IPP, respectively.

The Positive Predictive Value (PPV) of the combination of these ultrasound parameters were $72.37 \%$ for combined BWT and UEBW, $69.74 \%$ for BWT and IPP, $75.76 \%$ for UEBW and IPP, and $76.39 \%$ for combination of the 3 parameters Figs. $(3,4)$.

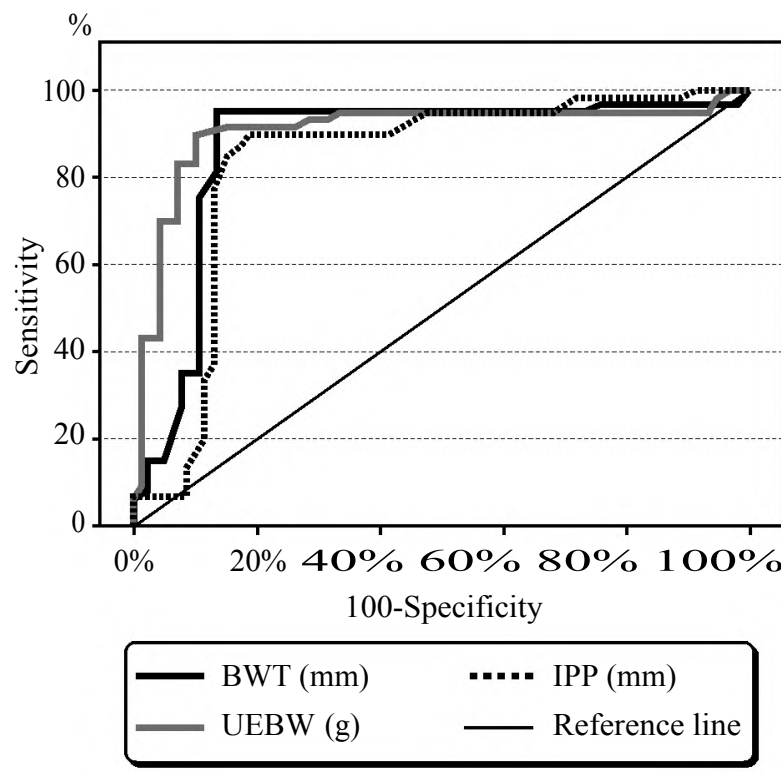

Fig. (2): ROC curve for BWT, UEBW and IPP. 

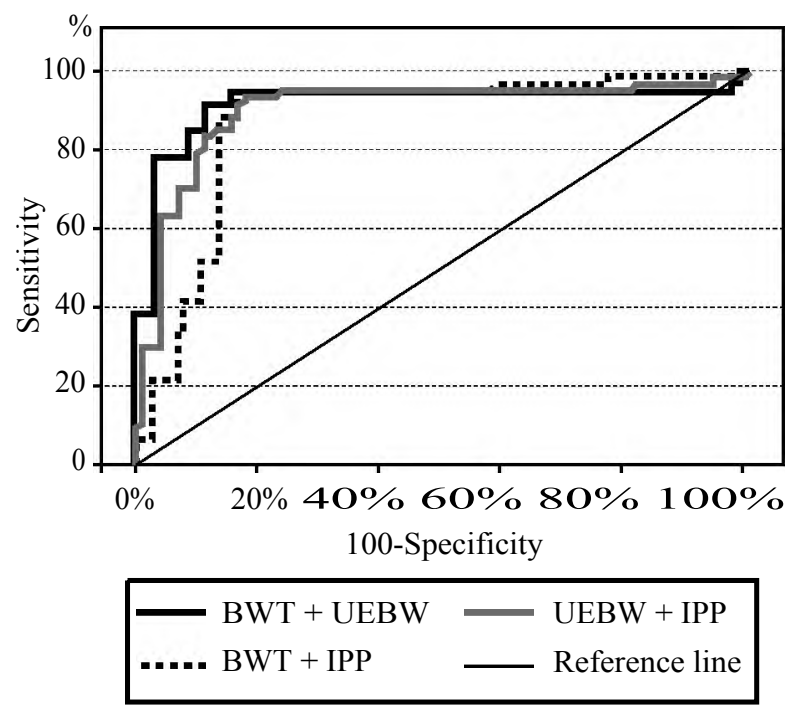

Fig. (3): ROC curve of combination of each parameter with others.

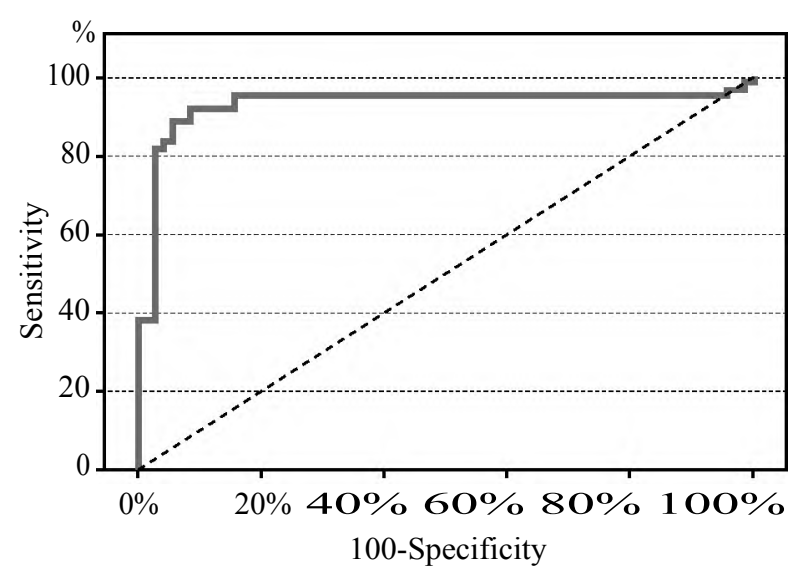

Fig. (4): ROC curve of combination of (BWT + UEBW + IPP).

\section{Discussion}

$\mathrm{BPH}$ is the most frequent cause of BOO in males over 50 years old complaining of LUTS [7].

Treatment options for BPH are; monitoring, medical or surgical treatment. Since the 1990s, there has been a change from surgical to medical therapy [8].

Alpha blockers are the most common used medication for treatment of LUTS/BPH, however, not everyone respond to alpha blockers and identification of baseline parameters that can predict the treatment outcome is needed [9].

Diagnosis of BOO cannot be made by symptomatic assessment alone as the use of I-PSS has a major limitation regarding its diagnostic specificity [10].
Post Voiding Residual urine (PVR) and prostate size are important in evaluation of BPH patients, but not crucial for diagnosis of obstruction. Several studies showed that urinary flow rate is the most reliable predictor of $\mathrm{BOO}$. Also several studies showed that transitional zone volume and ultrasound estimated prostate weight may also predict obstruction [11,12] .

Pressure Flow Studies (PFS) remain the best method of objective documenting BOO. But urodynamics still not routinely recommended in assessing BPH as it is invasive, time consuming and costy, so attempts have been made to evaluate non invasive parameters that can measure severity of LUTS and predict outcome of therapy [13].

$\mathrm{BOO} / \mathrm{BPH}$ is followed by compensatory increases in Bladder Wall Thickness (BWT) and bladder weight because of smooth muscle hypertrophy and decomposition of the connective tissue. Detection of these histological changes is important in the early stages of BOO to avoid complications and medical treatment failure $[\mathbf{1 4 , 1 5}]$

Ultrasonography (US) is a fast, non invasive, simple and acceptable method in evaluating detrusor muscle hypertrophy [16] .

A lot of studies concluded that BWT is correlated with grade of obstruction and has sensitivity and specificity similar to pressure flow studies in diagnosis of BOO [17,18] .

Oelke et al., concluded that BWT decreased speedily throughout the first $250 \mathrm{ml}$ of bladder filling but after that reached a plateau phase [19] There is also disagreement about the best cutoff value of BWT that can be diagnostic for BOO [15]

Manieri et al., used $5 \mathrm{~mm}$ as a cutoff point for BWT for diagnosis of BOO [20] on the other hand, Kessler et al., disagreed with Manieri et al., regarding the best cutoff point for BWT. They stated that BWT $2.9 \mathrm{~mm}$ is considered the best cut-off point with an elevated predictive value for BOO diagnosis [21]. This disagreement may be due to the use of different ultrasound techniques. Also these cut-off values are for diagnosis of $\mathrm{BOO}$ not for prediction of medical treatment response through correlation with follow-up data of Qmax, IPSS score and PVR after medical treatment [15].

According to our results; patients who had ineffective treatment outcome experienced significantly higher BWT than patients with effective treatment outcome at the same bladder volume as the BWT ranged from $9.60 \mathrm{~mm}$ to $13.10 \mathrm{~mm}$ in the 
ineffective treatment group while in the effective treatment group it ranged from $3.80 \mathrm{~mm}$ to $12.20 \mathrm{~mm}$.

The relation between BWT and response of LUTS to tamsulosin therapy in 74 patients with BPH was studied by Park et al., [22] and the results showed that, there was a negative correlation between BWT and the response of I-PSS score which agree with our results.

Salah Azab and Elsheikh [23] studied the effect of alfuzosin $10 \mathrm{mg}$ therapy on 125 patients with LUTS due to BPH. They divided the patients into 2 groups according to BWT and found that alfuzosin therapy is less satisfactory in patients with BWT more than $5 \mathrm{~mm}$ after 8 week of treatment which confirms the negative correlation between BWT and IPSS score improvement, PVR and Qmax after treatment.

Bladder hypertrophy grade can be evaluated by measurement of Ultrasound Estimated Bladder Weight (UEBW). Which made patients with LUTS could be evaluated according to bladder hypertrophy. Also, UEBW could be used as a reliable predictor of infravesical obstruction [24].

Kojima et al., reported that at cutoff value of $35.0 \mathrm{~g}$, UEBW predicted the infravesical obstruction with a diagnostic accuracy of $86.2 \%$. Thus, UEBW is considered to be a useful parameter representing the severity of BPH in terms of obstruction [25].

Kanyilmaz et al., concluded that the normal UEBW was $44.6 \pm 8.3 \mathrm{~g}$ by using $3 \mathrm{D}$ Bladder Scan BVM 6500, which is a portable ultrasound device [26] Also Ochiai and kojima reported that UEBW was higher in BPH patients (range 15.3 to $129.5 \mathrm{~g}$ ) than in those with a normal prostate (range 11.1 to $58.1 \mathrm{~g}$ ) and there were significant correlation between UEBW and the AUA symptom score, PVR, and prostatic volume [27]. According to our results UEBW ranged from 22.7 to $44.2 \mathrm{~g}$ in total studied patients with mean of $32.81 \pm 6.99$ standard deviation. Also UEBW was higher in the ineffective treatment group as it ranged from 37.6 to $44.2 \mathrm{~g}$ and there was a statistically significant positive correlation of UEBW with age, baseline IPSS score, prostate volume and BWT.

An anatomical configuration called the intravesical prostatic protrusion (IPP) can be measured noninvasively by transrectal ultrasonography (TRUS) and can predict voiding parameters for determining BOO in men with LUTS. IPP may also be a useful predictor for clinical progression in men with BPH [28].
Seo et al., concluded that alfuzosin is less effective in improving IPSS, Qmax and PVR in presence of IPP [4] . Also, Park et al., showed that tamsulosin is less effective in improving IPSS and Qmax in patients with moderate or severe IPP than in those with mild IPP [3].

Our results indicate a significant negative correlation between IPP and Qmax, $(p<0.05)$. Also pre-treatment IPSS values and post-treatment IPSS changes were found to have a significant correlation with IPP values $(p<0.05)$.

Keqin et al., and Reis et al., reported that ROC curves of IPP yielded an AUC of 0.858 and 0.758, respectively [29,30]. Keqin et al., [29] reported that the best cutoff was $7.5 \mathrm{~mm}$, while our best cutoff value for IPP to predict medical treatment failure was $8.2 \mathrm{~mm}$.

Our results showed that, the baseline BWT, UEBW and IPP were significantly correlated with the severity of symptoms and Qmax. Also patients in the ineffective treatment group experienced higher levels of BWT, UEBW and IPP. This finding, cope with most of previous studies, confirms the correlation of these ultrasound parameters to the severity of BOO.

In our study, the ultrasound morphologic parameters had significant effects on the overall treatment efficacy with favorable predictive value at cut-off values of $9 \mathrm{~mm}$ for BWT, $36 \mathrm{~g}$ for UEBW and $8.2 \mathrm{~mm}$ for IPP. The PPV and NPV of combination of these 3 parameters were higher than that for each particular parameter and $76.39 \%$ of patients with the 3 parameters exceeding the cut-off value had ineffective treatment. This observation can be used for identification of inappropriate candidates for Alpha1-AR Antagonist mono therapy. For patients with LUTS/BPH and baseline BWT $>9 \mathrm{~mm}$, UEBW $>36 \mathrm{~g}$ and IPP $>8.2 \mathrm{~mm}$, Alpha-AR Antagonist mono therapy would be ineffective for improving symptoms.

\section{Conclusion:}

Combined use of sonographic parameters BWT, UEBW and IPP can predict alpha 1 adreno receptor antagonist mono therapy outcome in BPH patients and aid in identifying proper candidates for therapy and determining patients at high risk of treatment failure.

\section{Acknowledgments:}

This research was carried out without funding.

Conflicts of interest:

No conflicts of interest declared. 


\section{Authors' contributions:}

All authors had equal role in design, work, statistical analysis and manuscript writing. All authors have approved the final article work.

\section{References}

1- KAPLAN S.A.: Factors in predicting failure with medical therapy for BPH. Reviews in urology. 7 (Suppl 7): p. S34, 2005.

2- ELKOUSHY M.A., A.M. ELSHAL and M.M. ELHILALI: Changing patients' profile presenting for surgical management of benign prostatic hyperplasia over the past 16 years: A single-centre perspective. Canadian Urological Association Journal, 9 (11-12): p. 372, 2015.

3- PARK H.Y., et al.: Efficacy of alpha blocker treatment according to the degree of intravesical prostatic protrusion detected by transrectal ultrasonography in patients with benign prostatic hyperplasia. Korean Journal of Urology, 53 (2): p. 92-7, 2012.

4- SEO Y.M. and H.J. KIM: Impact of intravesical protrusion of the prostate in the treatment of lower urinary tract symptoms/benign prostatic hyperplasia of moderate size by alpha receptor antagonist. International Neurourology Journal, 16 (4): p. 187, 2012.

5- HOMMA Y., et al.: Estimate criteria for efficacy of treatment in benign prostatic hyperplasia. International Journal of Urology, 3 (4): p. 267-73, 1996.

6- AHMED A.F.: Sonographic parameters predicting the outcome of patients with lower urinary tract symptoms/benign prostatic hyperplasia treated with alpha1adrenoreceptor antagonist. Urology, 88: p. 143-8, 2016.

7- MARTIN S.A., et al.: Prevalence and factors associated with uncomplicated storage and voiding lower urinary tract symptoms in community-dwelling Australian men. World Journal of Urology, 29 (2): p. 179-84, 2011.

8- McVARY K.T., et al.: Update on AUA guideline on the management of benign prostatic hyperplasia. The Journal of Urology, 185 (5): p. 1793-803, 2011.

9- DJAVAN B. and M. MARBERGER: A meta-analysis on the efficacy and tolerability of $\alpha 1$-adrenoceptor antagonists in patients with lower urinary tract symptoms suggestive of benign prostatic obstruction. European Urology, 36 (1): p. 1-13, 1999.

10- MADERSBACHER S., et al.: Is obstruction predictable by clinical evaluation in patients with lower urinary tract symptoms? B.J.U. International, 80 (1): p. 72-7, 1997.

11-KAPLAN S.A., et al.: Transition zone index as a method of assessing benign prostatic hyperplasia: Correlation with symptoms, urine flow and detrusor pressure. The Journal of Urology, 154 (5): p. 1764-9, 1995.

12- JEPSEN J.V. and R.C. BRUSKEWITZ: Comprehensive patient evaluation for benign prostatic hyperplasia. Urology, 51 (4): p. 13-8, 1998.

13-TE A. and S. KAPLAN: Urodynamics and benign prostatic hyperplasia. Textbook of Benign Prostatic Hyperplasia, 1: p. 187-98, 1996.
14- LEVIN R.M., et al.: Obstructive response of human bladder to BPH vs. rabbit bladder response to partial outlet obstruction: A direct comparison. Neurourology and Urodynamics, 19 (5): p. 609-29, 2000.

15- HAKENBERG O.W., et al.: Bladder wall thickness in normal adults and men with mild lower urinary tract symptoms and benign prostatic enlargement. Neurourology and Urodynamics, 19 (5): p. 585-93, 2000.

16- MÜLLER L., et al.: Standardized ultrasound method for assessing detrusor muscle thickness in children. The Journal of Urology, 164 (1): p. 134-8, 2000.

17- OELKE M., et al.: Increase in detrusor wall thickness indicates bladder outlet obstruction (BOO) in men. World Journal of Urology, 19 (6): p. 443-52, 2002.

18-FRANCO G., et al.: Ultrasound assessment of intravesical prostatic protrusion and detrusor wall thickness-new standards for noninvasive bladder outlet obstruction diagnosis? The Journal of Urology, 183 (6): p. 2270-4, 2010 .

19- OELKE M., et al.: Ultrasound measurement of detrusor wall thickness in healthy adults. Neurourology and Urodynamics, 25 (4): p. 308-17, 2006.

20- MANIERI C., et al.: The diagnosis of bladder outlet obstruction in men by ultrasound measurement of bladder wall thickness. The Journal of Urology, 159 (3): p. 7615,1998 .

21- KESSLER T.M., et al.: Ultrasound assessment of detrusor thickness in men-can it predict bladder outlet obstruction and replace pressure flow study? The Journal of Urology, 175 (6): p. 2170-3, 2006.

22- PARK J.S., et al.: Bladder wall thickness is associated with responsiveness of storage symptoms to alpha-blockers in men with lower urinary tract symptoms. Korean Journal of Urology, 53 (7): p. 487-91, 2012.

23- SALAH AZAB S. and M.G. ELSHEIKH: The impact of the bladder wall thickness on the outcome of the medical treatment using alpha-blocker of BPH patients with LUTS. The Aging Male, 18 (2): p. 89-92, 2015.

24- KOJIMA M., et al.: Ultrasonic estimation of bladder weight as a measure of bladder hypertrophy in men with infravesical obstruction: A preliminary report. Urology, 47 (6): p. 942-7, 1996.

25- KOJIMA M., et al.: Noninvasive quantitative estimation of infravesical obstruction using ultrasonic measurement of bladder weight. The Journal of Urology, 157 (2): p. 476-9, 1997.

26- KANYILMAZ S., et al.: Bladder wall thickness and ultrasound estimated bladder weight in healthy adults with portative ultrasound device. Journal of research in medical sciences: The Official Journal of Isfahan University of Medical Sciences, 18 (2): p. 103, 2013.

27- OCHIAI A. and M. KOJIMA: Correlation of ultrasoundestimated bladder weight with ultrasound appearance of the prostate and postvoid residual urine in men with lower urinary tract symptoms. Urology, 51 (5): p. 722-9, 1998.

28- LEE L.S., et al.: Intravesical prostatic protrusion predicts clinical progression of benign prostatic enlargement in patients receiving medical treatment. International Journal of Urology, 17 (1): p. 69-74, 2010. 
29- KEQIN Z., et al.: Clinical significance of intravesical prostatic protrusion in patients with benign prostatic enlargement. Urology, 70 (6): p. 1096-9, 2007.
30- REIS L.O., et al.: Intravesical protrusion of the prostate as a predictive method of bladder outlet obstruction. International Braz. J. Urol., 34 (5): p. 627-37, 2008.

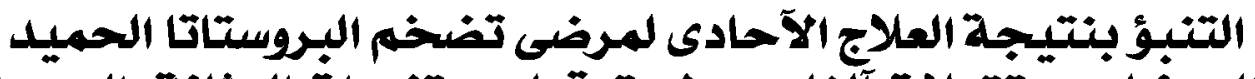

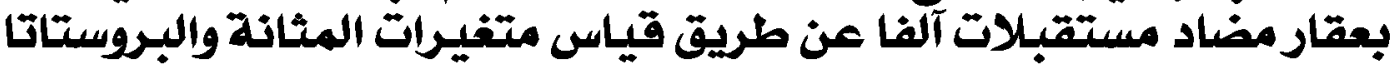 بإستخدام الموجات الفريق الفوق صوتياتية}

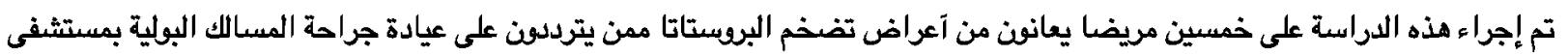

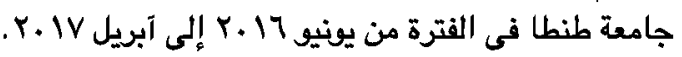

وقد تم إخضاع جميع المرضى للإختبارات المعملية الخاصة متمثة فى: زمن وتركيز بروثرومبين، تحليل بول كامل، مزرعة بول، وظائف كلى، تمليل دلالات آقوام البروستاتا.

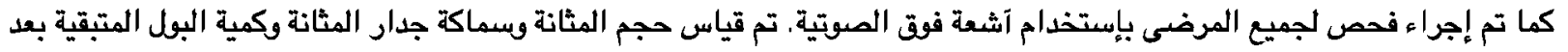

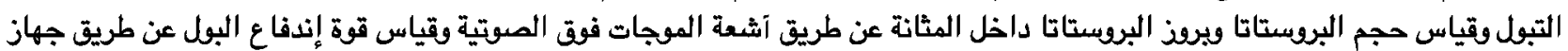
قياس ديناميكية التبول.

ثم إعطاء عقار تامسولوسين يوميا لمدة ثلاثة آشهر ثم متابعة المرضيى عن طريق قياس قوة إندفاع البول مرة آخرى بعد إنتهاء مدة العلاج

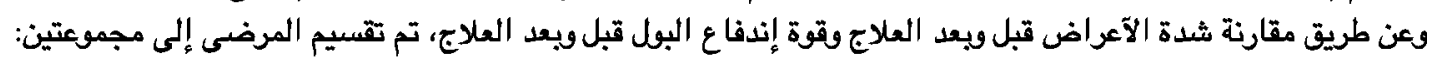

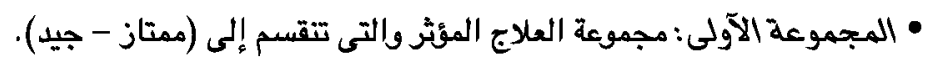

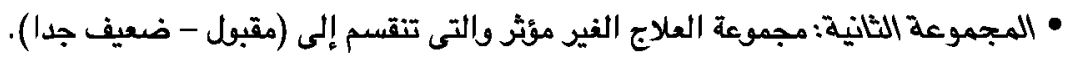

وعن طريق الرجوع إلى المتغيرات الآولية التى تم قياسها يتم حساب القيمة التتبوية لكل متغير على حدة والقيمة التنبؤية المتغيرات معا اللتنبؤ بنجاح العلاج الدوائي.

وتبين آنه يمكن إلى حد كبير التتبوّ بنجاح آو فثل العلاج الآحادى لمرضى تضخم البروستاتا الحميد بعقار التامسولوسين عن طريق قياس تلك المتغيرات قبل بداية العلاج. 